\title{
Formation of Jumantik Children from Android Bases to Increase the Success of Eradicating Mosquito Nests
}

\author{
Teguh Budiharjo ${ }^{1}$, Djoko Priyatno ${ }^{2}$ \\ \{teguhbudi41@ymail.com,djokopriyatnopoltekkessmg@gmail.com\} \\ Department of Health Analyst, Ministry of Health Polytechnic Semarang, Semarang, Indonesia
}

\begin{abstract}
Dengue Hemorrhagic Fever (DHF) is a health problem that is a concern. One of the counter measures for dengue fever is the mobilization of the larva (Jumantik) monitorer. School children are a community group that can play a strategic role. This activity is in an effort to increase the active role of school children as young jumantik. Use of an Android-based reporting application so that it is easy and fun to realize the Success of Raising Mosquito Nests. Data collection methods used were observation, and interviews and Focus Group Discussion (FGD) with School Health Unit Teachers, Principals, P2DBD data managers and Puskesmas heads. Larvae free numbers or "Angka Bebas Jentik" (ABJ) and countener index (CI) of 6 elementary schools is still low, namely ABJ (71\%) and CI (29\%). The second week of November, the average $\mathrm{ABJ}$ is low at $75 \%$. 3rd week results were better $(84 \%)$ than the previous week. In activities on the 4th month of November 2017 and the first month of December 2017 by Jumantik School Children get an increase in the number of free larvae of mosquitoes. The latest data from the activity was obtained by $\mathrm{ABJ}$ of $95,05 \%$ with a CI of $5 \%$.
\end{abstract}

Keywords: Jumantik, larvae free numbers, Android-based reporting

\section{Introduction}

In the city of Semarang, the parameters of dengue cases can be seen from the number of ABJ (larva free numbers) because they can predict the development of dengue cases. DHF prevention efforts are carried out by fumigation (fogging) and the mobilization of the larvae monitoring officer (Jumantik). School children, especially (elementary, junior high, high school) are a group of people who can play a strategic role, considering that there are very many around $20 \%$ of the population both in urban and rural areas. The role of school children as jumantik can be used to instill clean and healthy life behaviors (PHBS) at an early age.

Recording and reporting of Mosquito Nest Eradication and monitoring of mosquito larvae need to use media that is both easy and fun and avoids things that are difficult and boring. It is necessary to use an easy and fun application for jumantik school children in carrying out mosquito larvae monitoring activities and the Eradication of Mosquito Nests.Based on this background researchers are interested in empowering School Children as Jumantik by using an android-based application for reporting and documenting data. Easy and fun applications 
are expected to make mosquito larvae monitoring and Mosquito Nest Eradication activities interesting and routinely held continuously so that they can create a mosquito-free school environment.

\section{Methods}

Data collection methods used in this study were by observation, and interviews and Focus Group Discussion (FGD) with School Health Unit Teachers, Principals, P2DBD data managers and head of the Community Health Centers (Puskesmas) at the research location. The primary data on the success of eradicating mosquito nests was carried out by monitoring mosquito larvae by calculating $\mathrm{ABJ}$ and $\mathrm{CI}$ and $3 \mathrm{M}$ activities. Whereas for secondary data collected from reports of weekly activities at the Puskesmas, the monthly Jumantik report.

\section{Results and discussion}

The Eradication of Mosquito Nests in Primary Schools has been formally coordinated by Puskesmas officers in the Prevention of Disease (P2P) section through the School Health Unit Teachers. The second activity includes discussions in the form of a Focus Group Discision (FGD) intended to find out the activities and mechanisms that have been running at the school level, constraints on reporting and follow-up on the Eradication of Mosquito Nest data.

Manual mosquito larvae monitoring reporting mechanism is used as the basis for making models for making mosquito larvae monitoring systems by utilizing android applications using the Model Driven Development (MDD) method. Formation of Jumantik School Children is carried out through the stages of Socialization, Training and Implementation and Evaluation. Dissemination activities were carried out in each of the Elementary Schools which were the place for Jumantik School Children to involve the School Principal of the School Health Unitand the Disease Observation section of Rowosari Health Center, Gasurkes Officer (Health Surveillance Officer).

The training was attended by 51 participants consisting of 14 Health Analyst students as Activity Assistance, 6 School Health Unit Teachers as coaches, 30 elementary school students and one Health Center Disease Observation section. The training was conducted in 2 days consisting of 1 day theories of training material on Dengue Fever, Technique of managing mosquito larvae, Eradication of Mosquito Nests, Use of android applications for Mosquito Nest Eradication activities or monitoring of mosquito larvae, devices needed and procedures for using monitoring reporting applications mosquito larvae. The results of the Mosquito Eradication Eradication practice activities or monitoring of mosquito larvae are recorded by the system of recording android base reporting results as in table 1. 
Table 1. Monitoring of larvae in the first week of November 2017 by students (before the formation of the Jumantik)

\begin{tabular}{|c|c|c|c|c|}
\hline \multirow[t]{2}{*}{ No } & \multirow[t]{2}{*}{ Elementary School } & \multicolumn{3}{|c|}{ Information } \\
\hline & & Checked Place & Positive Larvae & ABJ / CI (\%) \\
\hline 1 & Meteseh & 14 & 4 & 71.4 / 28 \\
\hline 2 & Sendangmulyo1 & 13 & 4 & $69.2 / 30$ \\
\hline 3 & Sendangmulyo2 & 14 & 5 & $64.3 / 35$ \\
\hline 4 & Sendangmulyo3 & 15 & 4 & $73.3 / 26$ \\
\hline 5 & Sendangmulyo4 & 12 & 3 & $75.0 / 25$ \\
\hline \multirow[t]{2}{*}{6} & Ar Ridho & 13 & 4 & $69.2 / 30$ \\
\hline & Total & 81 & 24 & $71,0 / 29$ \\
\hline
\end{tabular}

The initial larva-free number of the activity as data before the School Children Jumantik Training and Formation activities, namely the larva-free number (ABJ) and the countener index (CI) were still relatively high, namely ABJ (71\%) and CI (29\%). The ABJ required by the Indonesian Ministry of Health is above $95 \%$.

Table 2. Monitoring of larvae in the first week of November 2017 by the companion (before the formation of the Jumantik)

\begin{tabular}{|c|c|c|c|c|}
\hline \multirow[t]{2}{*}{ No } & \multirow[t]{2}{*}{ Elementary School } & \multicolumn{3}{|c|}{ Information } \\
\hline & & Checked Place & Positive Larvae & ABJ / CI (\%) \\
\hline 1 & Meteseh & 15 & 3 & 80,0 / 20 \\
\hline 2 & Sendangmulyo 1 & 14 & 3 & $78.5 / 21$ \\
\hline 3 & Sendangmulyo2 & 14 & 5 & $64,2 / 35$ \\
\hline 4 & Sendangmulyo3 & 15 & 4 & $73,3 / 26$ \\
\hline 5 & Sendangmulyo4 & 16 & 3 & $81,1 / 18$ \\
\hline \multirow[t]{2}{*}{6} & Ar Ridho & 14 & 4 & $71,4 / 28$ \\
\hline & Total & 88 & 22 & $75,0 / 25$ \\
\hline
\end{tabular}

The results of the monitoring are directly included in the android base reporting system belonging to the companion (Health Analyst students) and the School Health Unit Teacher as the Jumantik Advisor. The average ABJ is high at $75 \%$. At that time we also conducted other Mosquito Nest Eradication activities related to the $3 \mathrm{M}$ program as a clean Friday activity.

Table 3. Monitoring of larvae in the 3rd week of November 2017 (after the formation of the Jumantik)

\begin{tabular}{clccc}
\hline No & Elementary School & Information & $\begin{array}{c}\text { Ind } \\
\text { Positive Larvae }\end{array}$ & ABJ / CI (\%) \\
\hline 1 & Meteseh & 15 & 2 & $86,6 / 13$ \\
2 & Sendangmulyo1 & 14 & 2 & $85,7 / 14$ \\
3 & Sendangmulyo2 & 14 & 3 & $78,6 / 21$ \\
4 & Sendangmulyo3 & 15 & 3 & $80,0 / 20$ \\
5 & Sendangmulyo4 & 16 & 2 & $87,5 / 12$ \\
6 & Ar Ridho & 14 & 2 & $85,7 / 13$ \\
& Total & $\mathbf{8 8}$ & $\mathbf{1 4}$ & $\mathbf{8 4 , 0} / \mathbf{1 6}$ \\
\hline
\end{tabular}

At the 3rd week as Jumantik School Children application activities using android as a mechanism for recording and reporting the results are obtained as in table 3 . ABJ at week 3 was better $(84 \%)$ compared to the previous week $(75 \%)$. 
Table 4. Monitoring of larvae in the 4th week of November 2017 (after the formation of the Jumantik)

\begin{tabular}{clccc}
\hline No & Elementary School & Checked Place & $\begin{array}{c}\text { Information } \\
\text { Positive Larvae }\end{array}$ & ABJ / CI (\%) \\
\hline 1 & Meteseh & 15 & 2 & $86,6 / 13$ \\
2 & Sendangmulyo1 & 14 & 1 & $92,8 / 7$ \\
3 & Sendangmulyo2 & 14 & 2 & $85,6 / 14$ \\
4 & Sendangmulyo3 & 15 & 1 & $93,3 / 7$ \\
5 & Sendangmulyo4 & 16 & 1 & $93,8 / 6$ \\
6 & Ar Ridho & 14 & 1 & $92,8 / 7$ \\
& Total & $\mathbf{8 8}$ & $\mathbf{8}$ & $\mathbf{9 0 , 9} / \mathbf{9}$ \\
\hline
\end{tabular}

Table 5. Monitoring of larvae in the first week of December 2017 (after the formation of the Jumantik)

\begin{tabular}{|c|c|c|c|c|}
\hline \multirow{2}{*}{ No } & \multirow{2}{*}{ Elementary School } & \multicolumn{3}{|c|}{ Information } \\
\hline & & Checked Place & Positive Larvae & ABJ / CI (\%) \\
\hline 1 & Meteseh & 15 & 1 & $93,3 / 7$ \\
\hline 2 & Sendangmulyo1 & 14 & 1 & $92,8 / 7$ \\
\hline 3 & Sendangmulyo2 & 14 & 1 & $92,8 / 14$ \\
\hline 4 & Sendangmulyo3 & 15 & 1 & $93,3 / 7$ \\
\hline 5 & Sendangmulyo4 & 16 & 0 & $100 / 0$ \\
\hline 6 & Ar Ridho & 14 & 1 & $92,8 / 7$ \\
\hline & Total & 88 & 5 & $95,05 / 5$ \\
\hline
\end{tabular}

In activities on the 4th month of November 2017 and the first month of December 2017 by Jumantik School Children get an increase in the number of free larvae of mosquitoes. The latest data from the activity was obtained by $\mathrm{ABJ}$ of $95,05 \%$ with a $\mathrm{CI}$ of $5 \%$.

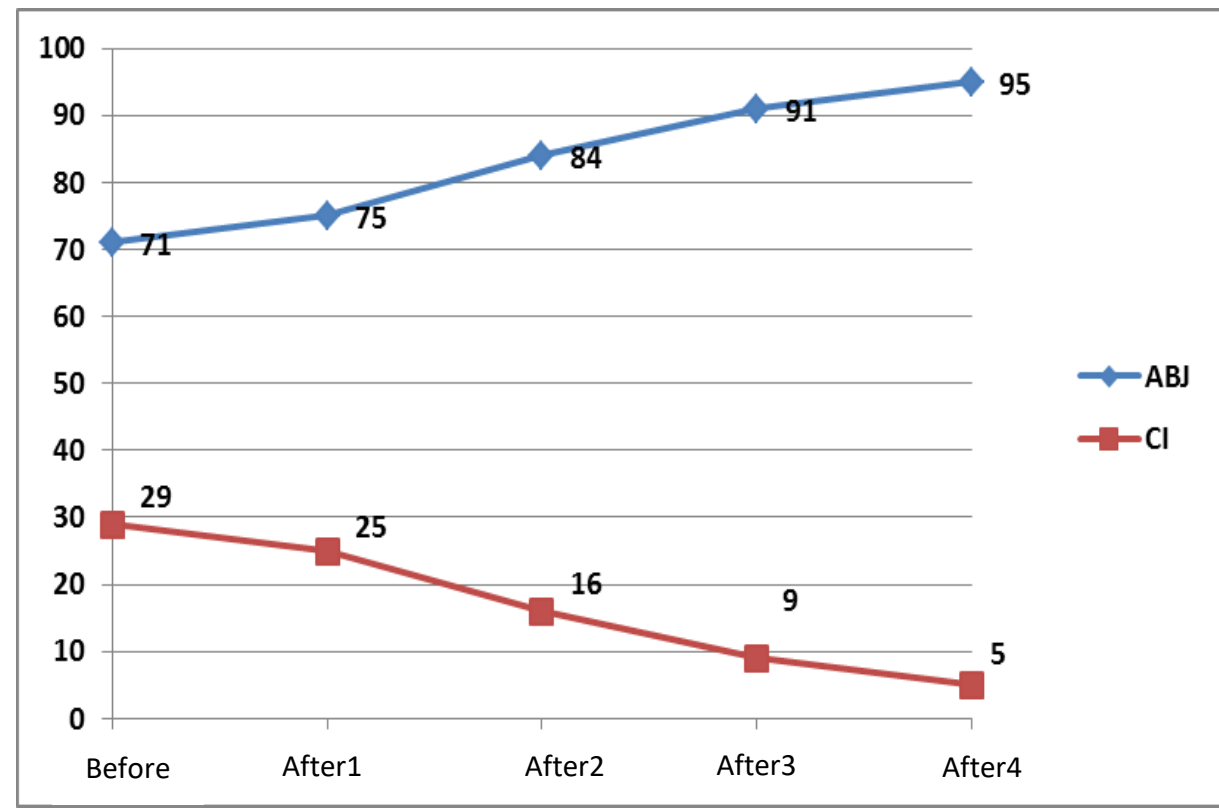

Fig 1. Graph of larva-free numbers (ABJ) and Countener Index (CI) in elementary schools before the formation and after formation of Jumantik school children. 
The last activity data shows in a good direction. The average ABJ number is close to $95 \%$. The minimum ABJ set by the Indonesian Ministry of Health is $95 \%$ with a CI value of $5 \%$.

\section{Conclusion}

1. Increasing the Eradication of Mosquito Nests in the school environment with the parameters of the Number of Free Larvae (ABJ) at the beginning of $71 \%$ after the formation of Jumantik School Children and conducting activities to $95 \%$. The original CI number was $29 \%$ to $5 \%$.

2. The use of information technology can increase the participation of elementary school students to be involved in monitoring mosquito larvae because android has become a technology that is used everyday, so that activities are more interesting.

\section{Acknowledgements}

The researcher would like to thank all those who contributed, especially to all elementary school principals (Sendangmulyo elementary school 1,2,3,4 and Ar Ridho elementary school) and the head of the UPTD Education Office in Tembalang District, Semarang City for their permission and support. The researcher would like to thank also the Semarang Health Ministry Polytechnic for funding support and all facilities used in this activity.

\section{References}

[1] Aditama, Tjandra Yoga. 2011. Modul pengendalian demam berdarah dengue. Jakarta: Kemenkes RI.

[2] Dinas Kesehatan Prov. Jawa Tengah. 2015. Buku Saku Triwulan 2 tahun 2015. Jawa Tengah: Dinkes Prov. Jateng.

[3] Hastuti, Oktri. 2008. Demam Berdarah Dengue. Kanisius, Yogyakarta. hal.7-8.

[4] Hutahaean, Jeperson.2015.Konsep Sistem Informasi Geografis. Deepublish, Yogyakarta. hal. 13.

[5] Kadir, Abdul. 2014. Pengenalan Sistem Informasi Edisi Revisi. Andi Offset, Yogyakarta.

[6] Kementerian Kesehatan RI. 2013. Buku Saku Pengendalian Demam Berdarah Dengue untuk pengelola program DBD puskesmas. Jakarta: Kemenkes RI.

[7] Kementerian Kesehatan RI. 2014. Petunjuk Teknis Jumantik - PSN Anak Sekolah. Jakarta: Kemenkes RI.

[8] Kementerian Kesehatan RI.2010.Profil kesehatan Indonesia. Jakarta: Kemenkes RI.

[9] Leod, Reymond Mc \& Schell, George P. 2008.Sistem Informasi Manajemen Edisi 11. Terjemahan oleh Ali Akbar Yulianto dan Afia R. Fitriati, Salemba Empat, Jakarta.

[10] Paryati \& Murya, Y. 2007.Sistem Informasi. Ardana Media, Yogyakarta. Vol.8.

[11] Santoso, S. \& Budiyanto, Anif. 2008. Hubungan Pengetahuan Sikap Dan Perilaku (PSP) Masyarakat Terhadap Vektor DBD Di Kota Palembang Provinsi Sumatera Selatan. Jurnal Ekologi Kesehatan; Vol. 7, Litbang Depkes. 